\title{
STRATEGI PERSONAL BRANDING MELALUI MEDIA SOSIAL INSTAGRAM (Analisis Isi pada Media Sosial MahasiswaUniversitas Kristen Satya Wacana)
}

\author{
Awallina Yusanda $^{1^{*}}$, Rini Darmastuti ${ }^{2}$, George Nicholas Huwae ${ }^{3}$ \\ 1,2,3 Fakultas Teknologi Informasi, Universitas Kristen Satya Wacana, Jl. Diponegoro 52-60 Salatiga \\ Email: 1"awallinay@gmail.com; ${ }^{2}$ rini.darmastuti@uksw.edu; ${ }^{3}$ nicholas.huwae@uksw.edu \\ *Penulis korespondensi
}

\begin{abstract}
ABSTRAK
Personal branding menjadi urgensi bagi setiap individu pada saat ini. Pada era digital ini, media massa dan media baru (termasuk Instagram) mempunyai peran sangat besar dalam membentuk personal branding seseorang, termasuk mahasiswa yang ada di Universitas Kristen Satya Wacana (UKSW). Berdasarkan latar belakang ini, maka tujuan dari tulisan ini adalah untuk mendiskripsikan strategi personal branding yang dilakukan oleh mahasiswa UKSW melalui instagram. Tulisan ini didasarkan dari hasil penelitian yang dilakukan dengan pendekatan kualitatif dan desain penelitian analisis isi. Hasil dari penelitian tersebut adalah, pertama, perilaku mahasiswa Universitas Kristen Satya Wacana dalam menggunakan instagram. Kedua, mahasiswa Universitas Kristen Satya Wacana yang sudah melakukan strategi personal branding di Instagram dengan pemilihan busana, mengunggah prestasi, dan menggunakan keterangan foto yang dapat memotivasi dan mahasiswa yang belum menerapkan strategi personal branding.
\end{abstract}

Kata kunci: Instagram, Personal Branding, Media Sosial.

\begin{abstract}
Personal branding is an urgency for every individual at this time. In this digital era, mass media and new media (including Instagram) have a very big role in shaping a person's personal branding, including students at Satya Wacana Christian University (SWCU). Based on this background, the purpose of this paper is to describe the personal branding strategy that SWCU students are doing through Instagram. This paper is based on the results of research conducted with a qualitative approach and content analysis research design. The results of this study are, first, the behavior of Satya Wacana Christian University students in using Instagram. Second, Satya Wacana Christian University students who have implemented a personal branding strategy on Instagram by selecting clothing, uploading achievements, and using photo captions that can motivate and students who have not implemented a personal branding strategy.
\end{abstract}

Keywords: Instagram, Personal Branding, Social Media.

\section{PENDAHULUAN}

Pada era digital seperti saat ini media sosial berkembang sangat pesat. Dengan adanya internet, masyarakat dapat memperoleh, mengelola, dan menyebarkan informasi dengan mudah. Setiap masyarakat yang terhubung pada suatu jaringan tertentu dapat mengakses internet kapan pun dan dimanapun. Terlebih saat ini terdapat media sosial yang banyak digunakan oleh anak muda yang membuat ruang privat seseorang menjadi konsumsi publik. Adanya pergeseran, dimana kini anak muda dapat dengan mudah membagikan segala kegiatan mereka yang bersifat pribadi untuk disampaikan ke pengguna lain melalui media sosial. Hal tersebut merupakan cara anak muda saat ini membentuk identitas diri mereka (Afriluyanto, 2018).

Salah satu media sosial yang saat ini banyak digunakan adalah Instagram. Instagram merupakan media sosial yang dapat mengunggah foto, membuat feeds, mengunggah Instastory, menggunakan filter pada foto, dan juga terdapat like dan followers yang dapat mempengaruhi presentasi diri (Setiawan \& Audie, 2020). Dengan adanya fitur-fitur yang dimiliki Instagram tersebut, maka dengan Instagram seseorang dapat melakukan personal branding (Afriluyanto, 2018). Semakin banyak masyarakat yang menggunakan Instgram, akan semakin banyak pula audience atau khalayak yang menerapkan ataupun mengamati Personal Branding yang dilakukan oleh pengguna Instagram tersebut. Membentuk Personal Branding dapat dijadikan sebagai cara untuk meningkatkan nilai jual seseorang. Personal Branding merupakan proses pembawaan keahlian, kepribadian, dan karakter seseorang dengan keunikan yang dimiliki untuk kemudian menjadi sebuah identitas (Agustinna et al., 2017). Beberapa situs pencatat data statistik penggunaan media sosial telah mengkalkulasi penggunaan media sosial Instagram di Indonesia seperti pada Gambar 1. 


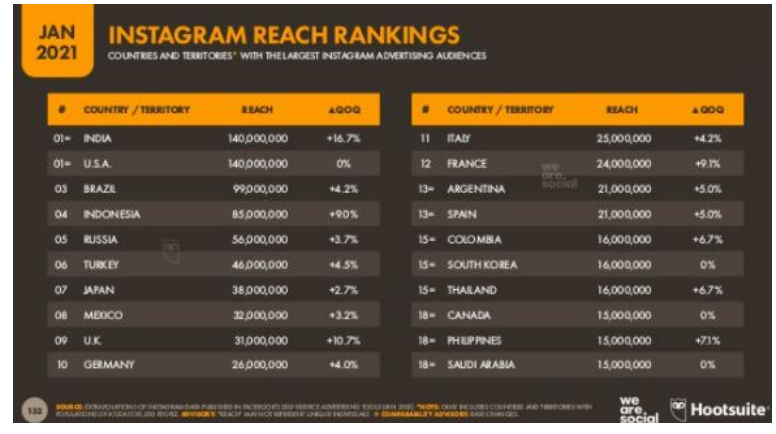

Gambar 1. Statistik "Hootsuite" peringkat negara pengguna instagram

Data pada Gambar 2 menunjukkan bahwa pengguna Instagram di Indonesia cukup tinggi, terlebih ketika melihat negara Indonesia berada pada posisi ke 4 dalam penggunakan media social. Di Indonesia, Instagram digunakan oleh masyarakat dari semua lapisan, mulai dari yang muda sampai yang tua. Instagram juga digunakan oleh semua masyarakat Indonesia dari semua profesi. Mulai dari anak-anak sekolah, mahasiswa maupun masyarakat yang sudah bekerja. Instagram menjadi media untuk menyampaikan pesan, baik itu pesan yang bersifat privat maupun yang sifatnya publik, dari seorang individu yang memiliki akun diinstagram kepada masyarakat.

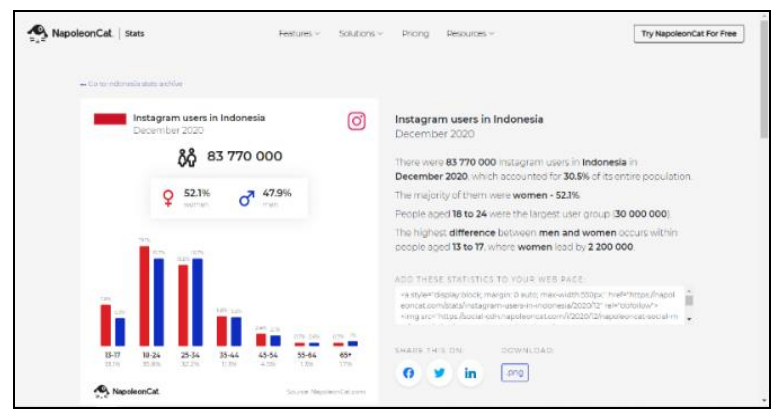

Gambar 2. Statistik "NapoleonCat" usia pengguna instagram

Pada tataran inilah tanpa kita sadari, Instagram mempunyai peran yang sangat besar untuk membangun 'konsep diri' dan citra diri seorang individu, kepada masyarakat luas. Instagram menjadi media untuk membangun 'branding'_seorang individu. Hal ini disebabkan karena rekam jejak setiap orang yang memiliki akun Instagram akan dapat diakses dengan mudah, dan akhirnya mampu membentuk personal branding. Sehingga dalam penelitian ini terdapat gap research bahwa saat ini, banyak perusahaan yang mengandalkan rekam jejak dari media sosial untuk mengetahui karakter dan jati diri calon karyawan, namun masih banyak yang belum menyadari akan hal tersebut. Fenomena ini menjadi fenomena yang menarik dan harus direspon secara cepat oleh calon pelamar pekerjaan, termasuk mahasiswa di Universitas Kristen Satya Wacana yang nantinya akan mencari pekerjaan. Seperti pada penelitian milik Dyah Arini Widyastuti tentang analisis personal branding di media sosial (Widyastuti et al., 2017). Pada penelitiannya, ia memaparkan bahwa dengan fitur yang disediakan oleh Instagram, seseorang dapat membranding dirinya dengan maksud menunjujan kredibilitas si pelaku, sehingga akan muncul kepercayaan dari orang yang mengunjungi halaman sosial media pemilik akun. Karena itu, menjadi urgensi bagi setiap mahasiswa untuk melakukan personal branding secara tepat di media sosial.

\section{TINJAUAN PUSTAKA}

\subsection{Personal Branding}

Personal Branding berasal dari Bahasa Inggris yaitu personal yang memiliki arti pribadi, dan branding sendiri diambil dari Bahasa Inggris branding yang memiliki arti membentuk brand atau merk. Sehingga Personal Branding dapat diartikan sebagai aktivitas yang dilakukan seseorang dalam menciptakan sebuah personal brand. Pada dunia usaha, brand diartikan sebagai pandangan atau emosi dari calon pembeli yang terbentuk melalui bermacam pengalaman pembeli terhadap suatu produk. Jika definisi tersebut diterapkan pada seseorang atau secara personal, personal brand merupakan sebuah pandangan dan emosi yang dimiliki seseorang pada diri orang tersebut yang mengartikan secara keseluruhan pengalaman dalam hubungan antarpersonal tersebut (McNally \& Speak, 2009). Pada tulisan milik Bambang Priyono ia menemuka bahwa personal branding merupakan sumber daya yang dimiliki pada setiap individu yang dapat diolah dan dikembangkan, dan faktor penentu utama dalam keberhasilannya adalah sumber daya itu sendiri (Priyono, 2014).

Selain teori milik McNally, pada tulisan ini penulis menggunakan teori milik Peter Montoya dalam bukunya yang berjudul "The Brand Called You: Create a Personal Brand That Wins Attention and Grows Your Business", terdapat tiga kunci utama untuk memenangkan personal branding. Elemen tersebut yang pertama, Clarity, personal branding dibentuk harus dapat memberitahukan siapa diri anda dan apa yang anda lakukan dengan spesifik. Hal tersebut dapat disampaikan melalui foto. Kedua, Specialization, untuk memenangkan personal branding, perlu menjadi berbeda untuk mendapat perhatian dengan memiliki keunikan. Ketiga, Consistency, setiap orang saling bersaing dalam membangun personal branding. 
Untuk mendapat perhatian, hal tersebut dapat diperoleh dengan disertai adanya konsistensi dalam melakukan personal branding (Montoya P, 2009). Sehingga dapat disimpulkan bahwa Personal Branding merupakan aktiviatas seseorang yang ditunjukan kepada individu lain melalui nilai-nilai atau kemampuan yang dimiliki sebagai sebuah identitas guna untuk meningkatkan nilai jual pada tiap individu.

\subsection{New Media}

Denis McQuail menyatakan bahwa media baru merupakan seperangkat teknologi elektronik yang memiliki perbedaan bagi setiap penggunanya. Media elektronik baru ini memiliki beberapa sistem diantaranya, system tranmisi (dengan satelit ataupun kabel), sistem miniaturisasi, sistem penyimpanan, dan pencari informasi, sistem yang mampu menyajikan gambar dengan kombinasi teks dan grafik, dan juga sistem pengendalian yang dapat dikendalikan melalui perangkat (Fitriyanti, 2017). Media baru berkembang sangat pesat di masyarakat seiring berkembangnya teknologi. Dengan begitu seseorang dapat dengan mudah berkomunikasi dengan rekan maupun pengguna media baru lainnya. Keunggulan yang dimiliki media baru adalah, media baru dapat membantu seseorang berkomunikasi tanpa memandang waktu dan tempat. Karena dengan media baru, seseorang dapat menggunakannya dimanapun, kapanpun, dan dengan siapapun. Oleh sebab itu adanya media baru ini sangat berguna bagi masyarakat luas.

\subsection{Media Sosial}

Media sosial menjadi wadah bagi seseorang sebagai wadah aktualisasi diri yang membentuk sebuah citra atau branding sesuai yang pengguna inginkan (Restusari \& Farida, 2019). Salah satu media sosial yang berkembang dan menjadi popular beberapa tahun belakang adalah Instagram. Instagram memberi fasilitas yang memudahkan penggunanya dalam membagikan foto, video dan jejaring sosial guna untuk membagikan kepada teman-temannya (Maulhayat et al., 2018). Dapat dilihat bahwa Instagram sebagai media sosial menjadi wadah aktualitas diri dengan membagikan foto, video, dan jejaringan sosial. Semua orang dapat menggunakan media sosial Instagram. Hanya dengan mendaftarkan dan mengikuti alur pendaftaran akun yang sudah Instagram sediakan, seseorang dapat langsung menggunakan dan menikmati fasilitas-fasilitas yang disediakan oleh Instagram. Dengan begitu, seseorang dapat dengan mudah berkomunikasi dengan pengguna lain dan berbagi konten dalam bentuk foto maupun video.

\subsection{Personal Branding pada Media Social}

Media sosial dapat mencerminkan penggunanya. Hal tersebut tertuang pada buku milik Muhamad Fadhol Tamimy dengan judul "Sharing-mu, Personal Branding-mu, Menampilkan Image Diri dan Karakter di Media Sosial" (Tamimy, 2017). Ia menyatakan bahwa seseorang dapat mengetahui karakter pemilik akun media sosial hanya dnegan melihat akun media sosial tersebut. Media sosial dapat mencerminkan karater yang dimiliki oleh pemiliknya. Sehingga tidak jarang jika media sosial digunakan sebagai sarana eksistensi diri atau branding. Hal tersebut yang menjadikan seseorang perlu menampilkan image atau kesan yang baik agar memiliki branding yang positif. Oleh karena itu, cara atau strategi branding pada media sosial perlu dilakukan dengan benar agar mendapat kesan yang diinginkan dari publik.

\section{METODE}

Tulisan ini menggunakan metode kualitatif. Pendekatan kualitatif adalah tradisi pada ilmu pengetahuan sosial yang secara dasar bergantung dengan pengamatan pada manusia dan berhubungan dengan orang-orang yang dimaksud dengan Bahasa dan istilahnya (Rahma, 2013). Objek dalam tulisan ini adalah akun Instagran (@himaadisha36) milik Himayani Adhisa mahasiswi Fakultas Psikologi, (@gabriellawd_) milik Gabriella mahasiswi Fakultas Teknologi Informasi, (@pspinatis) milik Pinkan mahasiswi Fakultas Teologi, (@ rinaldyrampalodji) milik Rinaldy Rampalodji mahasiswa Fakultas Ilmu Sosial dan Komunikasi. Teknik pengumpulkan data yang dilakukan adalah dengan observasi, wawancara, studi pustaka. Melalui data yang didapat, selanjutnya penulis melakukan analisis isi. Analisis isi merupakan penelitian yang bersifat mendalam terhadap pembahasan isi dari informasi yang tertulis atau tercetak yang dimuat pada media massa. Pelopor analisis isi sendiri adalah Harold D. Lasswell, dengan teknik symbol coding, yaitu mencatat lambang atau pesan yang terdapat pada sumber informasi secara sistematis, yang selanjutnya diberi interpretasi (Mawarni, 2016).

Menurut penulis, penentuan key person dengan menggunakan purposing sampling sehingga akun sebagai sumber data tidak didasarkan pada fakultas masing-masing pemilik akun, dimana satu fakultas tidak dapat mewakilkan fakultas lainnya. Pada tulisan ini menggunakan desain penelitian analisis isi. Sedangkan validitas data yang digunakan yaitu trianggulasi sumber, trianggulasi metode, dan trianggulasi teori. 


\section{PEMBAHASAN}

Membangun personal branding yang tepat menjadi kunci supaya dapat memenangkan kompetisi pada era digitalisasi pada saat ini. Melalui jaringan yang kita miliki, kita dapat menginformasikan siapa diri kita serta keahlian dan kredibilitas yang kita miliki. Strategi personal branding menjadi cara yang sangat efektif untuk memberitahukan siapa kita kepada target pasar secara cepat dan efisian. Hal ini seperti yang dikatakan oleh Rick Haskins, Multichannel News (Montoya, 2009: 3)

Developing a strong personal brand can be the key to rising above the competition. It serves as shorthand to convey your skill set and stylewhether you're a coordinator looking beyond your current job responsibilities or a midlevel network executive aiming for the presidency. Branding gives you an exceptionally effective way to broadcast who you are to your target market quickly and efficiently

Pernyataan Rick Haskins ini berlaku juga untuk mahasiswa di Universitas Kristen Satya Wacana. Supaya Menjadi urgensi bagi setiap mahasiswa di Universitas Kristen Satya Wacana, untuk membangun personal branding yang tepat supaya memenangkan dalam kompetisi ketika mencari kerja. Menurut Montoyo (2009 : 17), personal branding harus dibuat secara jelas, kuat dan menarik. Terkait hal ini Montoyo mengatakan, "A clear, powerful, compelling public image - that's the very definition of a Personal Brand". (Montoyo, 2009 : 17)

\subsection{Perilaku Mahasiswa Universitas Kristen Satya Wacana dalam Menggunakan Instagram}

Saat ini teknologi informasi berkembang sangat pesat, dengan hadirnya media baru (new media) dalam kehidupan manusia. Menurut Denis McQuail media baru merupakan seperangkat teknologi elektronik yang memiliki perbedaan bagi setiap penggunanya. Media elektronik baru ini memiliki beberapa sistem diantaranya, system tranmisi (dengan satelit ataupun kabel), sistem miniaturisasi, sistem penyimpanan, dan pencari informasi, sistem yang mampu menyajikan gambar dengan kombinasi teks dan grafik, dan juga sistem pengendalian yang dapat dikendalikan melalui perangkat (Fitriyanti, 2017). Salah satu media yang banyak digunakan masyarakat saat ini adalah Instagram. Instagram merupakan media sosial yang memberi fasilitas kepada penggunanya supaya memudahkan dalam membagikan foto, video dan jejaring sosial dengan tujuan supaya dapat dibagikan kepada teman-temannya (Maulhayat et al., 2018).
Dalam kehidupan ini, media baru hadir dengan beberapa tanda yang menyertainya. Hal ini seperti yang dikatakan oleh Rogers (Fitriyanti, 2017) bahwa terdapat tiga sifat utama yang menjadi tanda hadirnya teknologi komunikasi baru, yaitu interactivity, demasification dan asynchronous. Interactivity merupakan sistem komunikasi baru yang biasanya berisi perangkat komputer atau sejenisnya sebagai komponennya untuk berbicara balik kepada penggunanya seperti sebuah percakapan, De-masification menjelaskan tentang sifat media baru yang massal, dimana produsen komunikasi massa ini akan berpindah kepada konsumen media, Yang ketiga, asynchronous menjelaskan bahwa teknologi komunikasi baru mampu mengirim dan menerima pesan pada waktu-waktu yang diinginkan oleh penggunanya (Fitriyanti, 2017).

Apa yang disampaikan oleh Rogers ini, juga dialami oleh mahasiswa Universitas Kristen Satya Wacana yang menjadi narasumber dalam tulisan ini. Dilihat dari interactivity, sebagai sifat utama tanda hadirnya teknologi komunikasi baru ini juga dialami oleh mahasiswa UKSW yang menggunakan media baru. Sebagai media baru yang memiliki kemampuan untuk berbicara balik kepada penggunanya, media baru (dalam tulisan ini selanjutnya dituliskan dengan Instagram) menjadi media untuk membangun relasi dengan orang lain, baik untuk berkomunikasi, menjadi sarana menghibur diri atau untuk mengembangkan diri. De-manification, ditunjukan dengan pemilik akun sebagai produsen komunikasi yang mengunggah pesan berupa gambar di Instagram yang ditujukan kepada pengikutnya yang merupakan konsumen media. Dari wawancara yang dilakukan oleh penulis dengan narasumber, penulis menemukan fakta bahwa mahasiswa UKSW yang menjadi narasumber pada tulisan ini, mengunggah konten berupa foto atau video kapanpun mereka ingin tanpa ada jadwal tertentu. Mereka mengunggah foto ketika merasa ada foto yang menarik atau ketika mereka mengikuti kegiatan tertentu. Seperti yang dikatakan salah satu narasumber yang bernama Pingkan, ia berkata bahwa

Walaupun mereka menunggah foto tanpa ada jadwal tertentu, namun salah satu narasumber pada tulisan ini yaitu Himayani, sangat memperhatikan feeds pada Instagram miliknya. Ia mengatakan bahwa,

"Menurutku, pengaturan feeds di Instagram sangat penting. Walau aku jarang upload, yang penting feeds-ku enak dilihat"

Hal tersebut sejalan dengan hasil tulisan milik Rizki Setiawan dan Nurul Audie bahwa saat ini banyak pengguna Instagram yang mengatur feeds sebaik 
mungkin agar terlihat bagus. Maksud membuat feeds adalah, seperti membuat pola agar senada dan terlihat rapi satu baris yang sama (Setiawan \& Audie, 2020).

Selanjutnya, asynchronous hal tersebut ditunjukan dari sisi penggunaan, mahasiswa yang menjadi narasumber dalam tulisan ini, menggunakan media sosial selama 4-6 tahun. Dengan durasi penggunaan yang berbeda-beda yakni beberapa menit dalam satu kali membuka, hingga 3 jam penggunaan dalam satu kali membuka Instagram. Beberapa narasumber dalam tulisan ini, menggunakan Instagram sebagai media untuk menghibur diri dan menghilangkan rasa suntuk (bosan). Narasumber ini selalu menggunakan dan membuka Instagram pada pagi hari ketika mereka bangun tidur dan sebelum tidur. Sehingga tidak bisa dipungkiri bahwa Instagram merupakan media sosial yang menarik dan juga berguna bagi penggunanya.

Sebelumnya, Fries Maulhayat pernah meneliti tentang Peran Instagram di Kalangan Mahasiswa Angkatan 2015 Fakultas Ilmu Sosial Universitas Negeri Makassar (Maulhayat et al., 2018). Pada penelitian tersebut, penulis menemukan hasil bahwa peran Instagram di kalangan mahasiswa adalah sebagai ajang eksistensi diri dan juga sebagai pedoman cara berpakaian. Selain itu, Fries Maulhayat juga menemukan dampak sosial dan ekonomi dalam menggunakan media sosial Instagram. Hasil dari penelitian yang dilakukan oleh Maulhayat pada mahsiswa Fakultas Ilmu Sosial Universitas Negeri Makassar, juga dilakukan oleh mahasiswa UKSW yang menjadi narasumber pada tulisan ini. Penulis menemukan bahwa mahasiswa UKSW juga menggunakan media sosial Instagram sebagai sarana untuk ajang eksistensi diri. Hal tersebut ditunjukan dari hasil wawancara penulis dengan narasumber, Rinaldy memaparkan pendapatnya tentang kegunaan Instagram bahwa

"Instagram buat aku tu jadi wadah portofolioku terutama didunia permodelan"

Selain itu narasumber Pingkan juga memaparkan pendapatnya bahwa,

"Instagram tuh bisa jadi media portofolio berupa dokumentasi visual"

Dari pendapat dua narasumber tersebut, dapat dilihat bahwa kegunaan Instagram sebagai ajang eksistensi diri juga dilakukan oleh mahasiswa UKSW. Selanjutnya, kegunaan Instagram sebagai pedoman cara berpakaian juga dilakukan oleh mahasiswa UKSW yang menjadi narasumber pada tulisan ini. Hal tersbeut ditunjukan dengan fakta bahwa terdapat dua narasumber yang memiliki kesamaan role model. Gabriella dan Himayani merupakan narasumber yang sama-sama menyukai Awkarin. Awkarin merupakan selebgram yang cenderung mengenakan pakaian terbuka, bertato, sering mengumpat dan terkenal dengan julukan bad girl. Ketika wawancara Gabriella dan Himayani menyampaikan bahwa mereka menjadi diri sendiri dan berpakaian sesuai kenyamanan mereka. Namun mereka merasa memiliki kesamaan dengan Awkarin, sehingga dari hasil analisis isi pada akun Instagram mereka, penulis menemukan fakta bahwa cara Awkarin berbusana, sama dengan bagaimana Himayani dan Gabriella berbusana di Instagram. Sehingga dapat dilihat bahwa kegunaan Instagram sebagai pedoman cara berpakaian tidak hanya dilakukan oleh mahasiswa Fakultas Ilmu Komunikasi Universitas Negeri Makasar (UNM), namun juga dilakukan oleh mahasiswa UKSW yang menjadi narasumber tulisan ini. Selanjutnya dampak sosial dan ekonomi yang didapat dari penggunaan Instagram. Pada penelitian Maulhayat, peneliti menemukan bahwa pengaruh ekonomi yang didapat oleh mahasiswa UNM adalah adanya aktivitas jual-beli di Instagram yang marak dilakukan sehingga mahasiswa mengambil kesempatan tersebut untuk memulai bisnis. Dengan begitu, mahasiswa UNM dapat meningkatkan perekonomian mereka dari melakukan bisnis jual-beli tersebut. Hal tersebut juga dilakukan oleh beberapa mahasiswa UKSW yang menjadi narasumber pada tulisan ini. Rinaldy menggunakan Instagram sebagai sarana berbisnis. Hal yang dilakukan Rinaldy adalah membuka jasa titip barang. Selain itu Himayani juga berjualan makanan di Instagram. Sehingga dapat dilihat bahwa keggunaan Instagram sebagai sarana berbisbis memberi dampak bagi ekonomi mahasiswa juga di alami oleh mahasiswa UKSW yang menjadi narasumber pada tulisan ini.

\subsection{Strategi Personal Branding yang dilakukan Mahasiswa Universitas Kristen Satya Wacana}

Teori Dramaturgi milik Goffman, merupakan teori yang menjelaskan bahwa sebuah interaksi sosial dimaknai dengan pertunjukan teater atau drama di atas panggung (Suneki \& Haryono, 2017). Manusia berperan sebagai aktor yang mengembangkan perilaku-perilaku yang dapat mendukung perannya. Dari perilaku manusia tersebutlah yang kemudian menciptakan sebuah branding yang akan melekat pada dirinya yang kemudian menjadikan hal tersebut sebagai personal branding. Personal branding berperan sangat penting di kehidupan manusia, karena setiap hal yang dilakukan manusia dapat menjadi pembentuk personal branding yang kemudian menjadi pandangan orang lain.

Seperti yang dilakukan oleh mahasiswa Universitas Kristen Satya Wacana melalui sosial media Insta- 
gram. Pada tulisan ini, mahasiswa UKSW yang menjadi narasumberlah yang menjadi aktor dan Instagram sebagai wadah atau media sebagai panggung sandiwara atau teater. Dengan begitu, mereka dapat berperilaku sesuai keinginan mereka di Instagram. Dari perilaku yang mereka munculkan di instagramlah yang kemudian memunculkan personal branding. Mereka menggunakan media sosial Instagram sebagai sarana mem-branding diri mereka. Dengan foto, video berserta caption (keterangan) yang mereka unggah, dapat menggambarkan diri mereka yang kemudian menjadi sebuah personal branding. Pada tulisan ini, penulis menemukan dua kategori mahasiswa yaitu mahasiswa yang sudah menerapkan strategi personal branding dan mahasiswa yang belum menerapkan strategi personal branding. Hal tersebut ditunjukan dengan pemilihan busana yang dikenakan pada foto yang diunggah. Dua diantaranya yaitu Hima dan Gabriella memilih menggunakan busana yang terbuka dan dua diantaranya lagi memilih menggunakan busana yang sopan. Berkaitan dengan busana, dua narasumber pada tulisan ini memilih menggunakan busana yang sopan dan dua lainnya memilih menggunakan busana terbuka. Pemilihan busana tersebut memiliki makna bagi masing-masing narasumber. Pingkan sebagai narasumber yang memilih busana sopan menjelaskan bahwa,

"Semua itu kembali ke konten. Tergantung konten yang diunggah seperti apa. Ada banyak orang memang sengaja mengunggah konten dengan busana yang terbuka dengan tujuan mem-promote sesuatu. Itukan positif juga, tapi ya memang kembali lagi tergantung konten kegunaannya untuk apa"

Selain narasumber Pingkan, Rinaldy yang memilih menggunakan busana sopan juga menyampaikan pendapatnya mengenai busana bahwa,

"Sebenarnya baju tertutup tuh lebih baik dengan budaya kita. Cuma kalo kayak artis atau seleb gitukan bisa aja dia pakai baju yang terbuka karna kebutuhan. Kalo artis sih pasti busana buat di Instagram pasti penting banget, dipikirin mateng-mateng. Kalo aku sendiri sih busana sebenernya penting, Cuma dilihat lagi sama kebutuhannya. Kalo lagi ada kegiatan dan harus foto ya aku pilih jauh-jauh hari. Tapi kalo pas pergi kemana asal foto tapi bagus ya upload aja mau bajunya kayak gimana, asal bagus"

Melalui pernyataan yang Pingkan dan Rinaldy sampaikan berkaitan dengan teori milik Ronald Barthes pada buku The Language of Fashion (2005).
Dalam buku tersebut, Barthes mengaitkan konsep Bahasa, langue, dan parole dengan fashion. Ia menyatakan bahwa bahasa merupakan suatu aturan sosial dan fashion sebagai sistem tanda. Fashion sebagai language yang diartikan sebagai aturan sosial mengenai busana. Sedangkan parole merupakan tindakan secara individu dalam hal berbusana dan merupakan sebuah ekspresi seseorang dalam memilih dan mengenakan pakaian (Barthes, 2005). Pada teori semiology milik Barthes, fungsi tanda terdiri dari denotasi dan konotasi. Denotasi merupakan fungsi tanda sesungguhnya seperti, fungsi melindungi tubuh. Sedangkan makna konotasi, akan dikaitkan dengan fungsi sosial suatu fashion seperti, fungsi untuk menunjukan karakter seseorang. Sehingga secara semiologis, makna fashion sebagai penanda dan pertanda. Pada penelitian milik Muhammad Hasyim, ia menemukan bahwa fashion (busana) sebagai fenomena sosial dan budaya sertra praktik-praktik penanda, secara simbolis menunjukan bahwa fashion merupakan fungsi sosial dan budaya yang dapat melahirkan suatu rekontruksi makna dari fashion sebagai simbol (Muhammad, 2016). Hal tersebut sejalan dengan yang dilakukan mahasiswa Universitas Kristen Satya Wacana yang menjadi narasumber pada tulisan ini. Seperti yang disampaikan oleh Pingkan dan Rinaldy diatas, bahwa mereka memilih busana sesuai kebutuhan dan lebih memilih menggunakan busana yang sopan sebagai busana terbaik yang dikenakan untuk diunggah di sosial media Instagram. Selain narasumber Pingkan dan Rinaldy, narasumber lainnya yaitu Gabriella dan Himayani juga menyatakan pendapatnya mengenai busana. Gabriella menyampaikan bahwa,

"Aku pengen terlihat bebas dan tanpa aturan, selama aku jadi diriku sendiri dan tidak mengganggu atau merugikan siapapun. Aku menerima kalau orang memandang aku dengan image buruk, ya karena memang aku begini"

Himayani juga berpendapat bahwa, "Aku cuma berusaha jadi diri sendiri di Instagram, aku pake yang aku nyaman aja. Kadang kebayang sih omongan orang kalo dibilang nakal. Tapi aku bodo amat, emang fashion aku gitu kok. Kalo terus-terusan ikutan orang lain ya aku ga bisa jadi diri sendiri"

Sehingga dari seluruh pernyataan narasumber dari wawancara yang dilakukan, masing-masing narasumber memiliki alasan tersendiri dalam memilih busana. Narasumber Pingkan dan Rinaldy memilih menggunakan pakaian sopan untuk membentuk karakter baik agar memunculkan perpektif positif. 
Sedangkan narasumber Gabriella dan Himayani menyatakan bahwa mereka tidak terlalu memikirkan busana yang dikenakan pada foto yang mereka unggah di Instagram. Mereka mengenakan busana yang menurutnya nyaman dan ingin menjadi diri sendiri. Bagi mereka, tidak masalah jika mendapat prespektif negatif selama mereka merasa nyaman menjadi diri sendiri dan tampil apa adanya di akun instaram milik mereka. Maka dari itu, melalui teori Ronald Barthes dapat dilihat bahwa fungsi fashion (busana) sebagai simbol yang menjadi faktor pembentuk personal branding sudah diterapkan oleh narasumber Pingkan dan Rinaldy dengan menghasilkan perspektif positif. Sedangkan narasumber Gabriella dan Himayani yang memilih mengenakan busana sesuai apa yang mereka ingin, menghasilkan perspektif negatif karena busana yang mereka kenakan cenderung terbuka. Dengan budaya Indonesia yang ada saat ini, bahwa dalam berbusana terdapat etika yang perlu diperhatikan yaitu untuk menutup aurat (Dakwah et al., 2018).

Selain busana, melalui caption (keterangan foto), penulis menemukan bahwa dua diantaranya memilih menggunakan bahasa yang kasar ysng berisi umpatan, dan dua lainnya yaitu Rinaldy dan Pingkan memilih menggunakan Bahasa yang sopan yang berisi hal-hal yang dapat memotivasi. Melalui wawancara yang dilakukan penulis dengan narasumber, mahasiswa yang memilih menggunakan busana terbuka dan menggunakan kata kasar pada caption, menyampaikan bahwa tidak masalah jika seseorang menganggap dirinya dengan branding sebagai bad girl (wanita nakal). Hal tersebut bukan semata-mata terlihat bad girl, namun mereka menjelaskan bahwa apa yang mereka lakukan tersebut adalah upaya mereka dalam menjadi diri sendiri dan tidak perpurapura di media sosial. Mereka juga memiliki role model (panutan) yang sama yaitu Awkarin. Awkarin merupakan selebgram dengan personal branding bad girl. Mereka merasa, Awkarin memiliki kepribadian yang mirip dengannya sehingga menjadikan Awkarin sebagai panutan dalam menggunakan media sosial Instagram. Penulis juga melakukan wawancara kepada Rinaldy dan Pingkan narasumber yang memilih menggunakan busana sopan dan juga menggunakan caption yang memotivasi. Selain itu, mereka juga mengunggah prestasi yang mereka raih ke Instagram. Penulis melakukan wawancara dengan Pingkan, ia mengatakan bahwa

"Aku berharap kalau aku upload prestasi di Instagram, itu bisa memotivasi orang lain agar terpacu untuk berprestasi juga. Aku sadar banget soal Personal Branding, karena menurutku saat melamar kerja nanti atau study lanjut dan bertemu orang baru, orang jaman sekarang cenderung mencari Instagram kita terlebih dahulu sebelum mengenal langsung. Nah, dari apa yang kita post kan bisa dilihat kita tuh pribadi yang seperti apa dan kalau orang sudah melihat kepribadian kita seperti itu, orang akan menanamkan pandangan itu dengan jangka waktu yang lama. Apa yang dilihat sekarang, itu akan berpengaruh ke pandangan orang ke kita nantinya"

Selain Pingkan, Rinaldy juga menyampaikan pendapatnya tentang personal branding. Ia menyampaikan bahwa,

"Prestasi yang diunggah di Instagram tuh penting. Karena sebagai yang punya akunkan pengennya dilihat yang baik-baik sama orang, because brand your self is about how you greatings.Makanya upload prestasi di Instagram tuh penting, biar dilihat baik"

Sehingga dapat dilihat bahwa bagi mereka menyesuaikan busana sesuai kondisi dan memilih busana yang sopan, memilih penggunaan bahasa yang baik dan memotivasi pada caption, serta mengunggah prestasi yang dicapai merupakan strategi yang mereka lakukan untuk memperoleh personal branding yang baik. Mereka beranggapan bahwa personal branding sangatlah penting, karena apa yang orang lain lihat di Instagram, dapat menggambarkan diri mereka dan apa yang orang lain lihat saat ini dapat mempengaruhi pandangan orang lain di kemudian hari. Menurut mereka, Instagram merupakan dokumentasi visual. Selain itu mereka juga menyampaikan bahwa, saat ini seseorang cenderung melihat akun Instagram orang lain sebelum mengenal langsung. Sehingga melalui hal tersebut, Instagram berperan penting dalam menggambarkan tentang bagaiman dirinya. Hal tersebut sejalan dengan teori milik Erving Goffman yang memaparkan dalam konsep Dramaturgi miliknya bahwa, individu akan berlomba-lomba menampilkan dirinya sebaik mungkin. Goffman berasumsi bahwa saat seseorang berinteraksi dengan orang lain, mereka ingin menyajikan suatu gambaran diri yang akan diterima orang lain. Upaya ini disebut juga dengan pengelolaan kesan (impression management), (Ridho, 2016). Teori tersebut jika dikaitkan dengan apa yang dilakukan oleh Rinaldy dan Pingkan, maka dapat dilihat bahwa mereka melalukan pengelolaan kesan dengan menunjukan sisi-sisi positif yang mereka miliki melalui unggahan foto dan keterangan foto di Instagram. Hal tersebut menunjukan usaha mereka untuk diterima orang lain dengan sisi terbaik yang mereka miliki. 
Dari pernyataan Pingkan dan Rinaldy diatas mengenai pendapatnya tentang personal branding, dan apa yang dilakukan Pingkan dan Rinaldy dalam mengunggah prestasi yang mereka raih diikuti dengan caption yang memotivasi ini, sejalan dengan penelitian milik Etty Achmad, (Achmad, 2020). Pada penelitiannya tentang personal branding pada remaja melalui Instagram, ia menemukan fakta bahwa dengan menunjukan sisi positif di Instagram, seseorang akan mendapat kepercayaan dari orang lain. Selain itu, menunjukan sisi positif di Instagram merupakan sebuah usaha agar seseorang tersebut terlihat sinkron dengan dunia nyata dan memunculkan kepercayaan orang lain. Hal yang dilakukan Pingkan dan Rinaldy merupakan cara mereka untuk menunjukan adanya keseimbangan antara media sosial dengan dunia nyata. Mereka melakukan hal tersebut agar mendapat kepercayaan orang lain terhadap mereka, serta dapat memberi manfaat terhadap pengikutinya, agar termotivasi untuk turut serta berprestasi. Apa yang Pingkan dan Rinaldy lakukan dalam strategi personal branding, berkaitan dengan teori retorika milik Aristoteles. Aristoteles mengartikan bahwa retorika merupakan seni persuasi yang bersifat singkat, jelas, dan meyakikan guna untuk memperbaiki, memerintah, mendorong, dan mempertahankan (Putri et al., 2017). Strategi personal branding yang dilakukan Pingkan dan Rinaldy dengan mengunggah prestasi yang mereka miliki ke Instagram diikuti dengan keterangan foto yang mengandung motivasi, berkaitan dengan teori retorika. Hal tersebut dilakukan guna untuk mendapat kepercayaan dari pengikutnya di Instagram yang kemudian dari kepercayaan itu, dapat memunculkan prespektif positif.

Selain itu, narasumber Pingkan menyampaikan bahwa jumlah like pada foto penting bagi dirinya. Ia menyatakan bahwa,

"Setiap kali aku upload foto, aku selalu merhatiin jumlah like di foto yang habis aku upload. Karena kalau missal jumlah like terlalu sedikit, aku pasti mikir, apa ada yang salah dari fotoku ya? Jadi menurutku jumlah like pada sebuah postingan foto sangat penting. Bisa aja ternyata orang gak suka sama foto itu jadi gak like"

Hal tersebut sejalan dengan penelitian milik Sheldon dan Bryant, bahwa bagi sebagian pengguna Instagram jumlah like pada foto sangat berpengaruh (Sheldon \& Bryant, 2016). Hal yang dilakukan oleh Pingkan merupakan salah satu usahanya untuk melihat seberapa besar orang orang menerimanya melalui foto yang ia unggah dengan melihat jumlah like pada foto yang ia unggah.
Sehingga dapat dilihat bahwa strategi personal branding yang sudah dilakukan oleh mahasiswa UKSW yang menjadi narasumber tulisan ini adalah dengan pemilihan busana sesuai kebutuhan dan juga menggunakan busana yang sopan untuk diunggah ke Instagram, pengunggahan prestasi di Instagram yang berguna untuk memacu diri untuk terus berprestasi dan memotivasi pengikutnya di Instagram agar turut berprestasi, pemilihan bahasa yang santun dalam pembuatan caption serta dengan kalimat yang dapat memotivasi atau kalimat yang memberi semangat, agar pembaca mendapat manfaat dari membaca caption yang mereka buat.

Menurut teori yang dipaparkan oleh McNally, terdapat tiga hal utama pembentuk Personal Branding (McNally \& Speak, 2009) yaitu, yang pertama kompetensi atau kemampuan yang dimiliki tiap individu guna membangun personal branding, seseorang harus memiliki kemampuan tertentu atau kompetensi pada sebuah bidang yang dapat dikuasai. Seseorang dapat melakukan personal branding dengan memoles cara komunikasi yang sudah direncanakan dengan baik. Personal Branding merupakan sebuah gambaran tentang apa yang seseorang pikirkan pada orang lain. Hal tersebut menggambarkan nilai-nilai, kepribadian, keahlian, dan kualitas yang menjadikan seseorang memiliki perbedaan satu dengan yang lain. Kedua, gaya yang dapat menunjukan kepribadian yang dimiliki setiap individu dari personal branding disebut juga dengan gaya. Gaya merupakan elemen yang menjadikan seseorang unik menurut orang lain. Terkadang penilaian seseorang terhadap orang lain dapat mengndung emosi yang kuat. Ketiga, standar yang dapat mempengaruhi pandangan orang lain terhadap pelaku personal branding dan standarlah yang akan memberikan makna terhadap kekuatan personal branding yang dilakukan. Selain itu, standar sendiri ditetapkan oleh orang yang melakukannya. Melalui teori tersebut, mahasiswa Universitas Kristen Satya Wacana yang menjadi narasumber yang telah menerapkan strategi personal branding menggunakan aspek gaya dengan memilih menggunakan busana sesuai kebutuhan dan memilih busana yang sopan seperti yang dilakukan oleh narasumber Rinaldy dan Pingkan. Selanjutnya, aspek kompetensi dan kemampuan ditunjukan dengan mengunggah prestasi yang diraih ke Instagram seperti yang dilakukan Rinaldy dan Pingkan dengan mengunggah foto ketika mereka memenangkan ajang pemilihan Mas dan Mbak kota. Kemudian pada aspek standar ditunjukan dengan pemilihan foto yang diunggah dengan diikuti keterangan foto dengan bahasa yang sopan dan tidak menyinggung pihak 
manapun. Hal tersebut dilakukan oleh Rinaldy dan Pingkan, dengan hanya mengunggah foto yang menurut mereka bagus dan foto saat mereka mengikuti acara tertentu. Foto yang menurut mereka bagus adalah bentuk standar yang mereka buat untuk menentukan apakah foto tersebut layak untuk diunggah ke Instagram atau tidak. Hal tersebut penulis gambarkan dalam flow chart berikut,

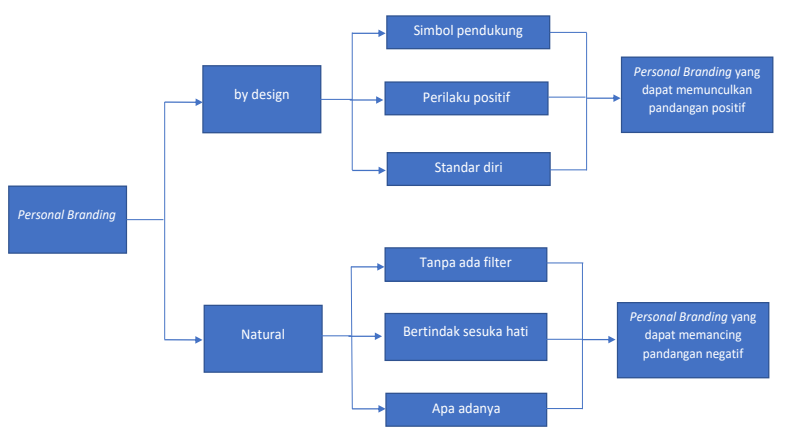

Gambar 3. Flow chart personal branding

Flow Chart pada Gambar 3 menggambarkan temuan dari penelitian yang telah dilakukan, bahwa jika seseorang ingin memperoleh personal branding yang baik, seseorang perlu melakukan strategi personal branding yang baik pula. Pelaku dapat menerapkan dengan menunjukan hal-hal positif seperti menggunakan simbol pendukung mengunggah foto dengan busana sesuai kebutuhan karena busana merupakan simbol, berperilaku positif dengan menggunakan kalimat yang baik tanpa menggunakan kata yang kasar pada keterangan foto, serta menetapkan standar diri salah satunya dengan menunjukan prestasi yang diraih karena prestasi dapat dijadikan standar tergantung pada masing-masing individu. Namun, jika seseorang mengunggah konten di Instagram tanpa menggunakan strategi personal branding, maka mereka mengunggah apa adanya mereka tanpa mempertimbangkan hal-hal yang secara tidak langsung dapat memunculkan branding yang negatif. Hal tersebut menunjukan bahwa seseorang yang melakukan personal branding yang baik, memiliki pandangan jauh ke depan atau visioner. Karenanya, branding yang dimiliki seseorang di sosial media, dapat berpengaruh dalam kehidupan sehari-hari, baik saat ini maupun di kemudian hari. Dampak yang didapat dari kesan atau branding pada media sosial adalah, ketika seseorang akan menjalankan bisnis atau melamar pekerjaan, orang cenderung memilih seseorang yang memiliki branding baik. Sedangkan seseorang yang memiliki branding yang buruk, orang akan enggan melakukan kerjasama dengannya. Hal tersebut menunjukan begitu besarnya pengaruh personal branding bagi seseorang. Dengan begitu, seseorang perlu memahami strategi personal branding yang tepat utnuk mendapat branding yang baik. Hal tersebut tertuang pada teori milik Muhamad Fadhol Tamimy (Tamimy, 2017) bahwa, karakter seseorang dapat tergambar pada sosial media yang mereka miliki sehingga seseorang perlu menampilkan hal-hal positif agar mendapat kesan yang positif dari publik. Pada tulisan ini, strategi personal branding perlu dilakukan oleh mahasiswa, karena hal tersebut dapat berpengaruh ketika mahasiswa akan mencari pekerjaan ataupun akan masuk di lingkungan yang baru.

\section{KESIMPULAN}

Tulisan ini mendeskripsikan tentang strategi yang dilakukan mahasiswa Universitas Kristen Satya Wacana dalam melakukan personal branding melalui Instagram. Berdasarkan hasil analisis dan pembahasan, penulis menemukan hasil sesuai rumusan masalah tulisan ini yang pertama adalah perilaku mahasiswa UKSW dalam menggunakan Instagram. Mahasiswa UKSW menggunakan Instagram sebagai media komunikasi, hiburan, sarana aktualitas diri, dan juga berbisnis. Mahasiswa UKSW dapat berkomunikasi baik dengan orang baru maupun orang yang sudah dikenal. Selain itu, bagi mahasiswa UKSW, Instagram adalah media sosial yang menarik untuk mengisi waktu sebagai hiburan. Instagram juga digunakan sebagai sarana aktualitas diri melalui foto yang diunggah sebagai dokumentasi visual. Mahasiswa UKSW juga menggunakan Instagram sebagai sarana berbisnis. Kedua, penulis menemukan strategi yang dilakukan oleh mahasiswa UKSW dalam melakukan personal branding melalui Instagram adalah dengan pemilihan busana sesuai kebutuhan dan menggunakan busana yang sopan, menggunakan caption yang tidak menyinggung dan mengandung motivasi, serta mengunggah prestasi yang telah diraih ke Instagram.

Tulisan ini juga mengungkap bahwa terdapat dua kategori mahasiswa di antaranya, mahasiswa yang sudah melakukan strategi personal branding dengan pemilihan busana, mengunggah prestasi, dan menggunakan keterangan foto yang dapat memotivasi dan mahasiswa yang belum melakukan strategi personal branding. Mahasiswa yang belum sadar akan pentingnya melakukan strategi personal branding, cenderung bersikap apa adanya dan menjadi diri sendiri tanpa mem-filter hal-hal yang sekiranya dapat menimbulkan branding negatif bagi dirinya.

Berdasarkan hasil analisis dan pembahasan, saran yang penulis ingin sampaikan kepada penguna 
Instagram adalah pentingnya melakukan strategi personal branding. Terutama bagi mahasiswa yang akan terjun ke dunia kerja maupun yang akan bertemu dengan lingkungan yang baru, strategi personal branding sangatlah penting dilakukan. Jika seseorang melakukan startegi personal branding, maka orang tersebut dapat membentuk bagaimana ia ingin dilihat oleh lingkungannya. Apa yang seseorang bentuk melalui stategi personal branding, hal itulah yang akan dilihat oleh orang lain sehingga memunculkan personal branding.

\section{DAFTAR PUSTAKA}

Achmad, E. S. (2020). Personal branding pada remaja melalui instagram.

Afriluyanto, T. R. (2018). Fenomena Remaja Menggunakan Media Sosial dalam Membentuk Identitas. KOMUNIKA: Jurnal Dakwah Dan Komunikasi, 11(2), 184-197. https://doi.org/10.24090/ komunika.v11i2.1365

Agustinna, K., Purnama, H., \& Abdurrahman, M. S. (2017). Kata kunci: Personal Branding, Instagram, Selebgram Keywords: Personal Branding, Instagram, Selebgram. Analisis Strategi Personal Branding Melalui Media Sosial Instagram, 4(1), 1028-1036.

Dakwah, F., Komunikasi, D. A. N., Ar-raniry, U. I. N., \& Aceh, B. (2018). Etika berbusana (. 118. https://repository.ar-raniry.ac.id/id/eprint/4720/2/ Nurul Faraiyah Binti Abu Bakar.pdf

Fitriyanti, N. (2017). Facebook dan Instagram sebagai media publishing karya komikus di Melati Komik Studio Surabaya. UIN Sunan Ampel Surabaya., 1, 1-476. https://doi.org/10.1017/ CBO9781107415324.004

Joko, B., Praktisi, P., \& Lia, D. (2014). Strategi Menciptakan, Mempertahankan Dan Menjual Personal Branding Jelang Pemilu 2014. Jurnal Visi Komunikasi, 13(02), 265-280.

Maulhayat, F., Kesuma, A. I., \& Amiruddin, H. (2018). Peran Instagram di Kalangan Mahasiswa Angkatan 2015 Fakultas Ilmu Sosial Universitas Negeri Makassar. 1-18. http://eprints.unm.ac.id/ 9871/\%0Ahttps://id.wikipedia.org/wiki/Instagra mSeiri

Mawarni, A. D. (2016). Analisis Isi Pada Artikel Romansa Di Zetizen . Com ( Studi Analisis Isi Artikel Romansa Pada Web Zetizen Periode 1 Oktober-30 November 2016 ). November, 1-10.

McNally, D., \& Speak, K. D. (2009). Be Your Own Brand: A breakthrough formula for standing out from the crowd. 1-141. https://www.bkconnection.com/static/Be_Your_Own_Brand_EXCER PT.pdf
Muhammad, H. (2016). Fashion Sebagai Komunikasi: Analisis Semiotis Atas Fashion Jokowi Pada Pemilihan Presiden 2014. Icmr, 6-8.

Putri, D. M., Sos, S., \& Si, M. (2017). Analisis Retorika Pada Pembentukan Personal Branding Sandiaga Uno Sebagai Pemimpin Publik Pilkada 2017 Oleh. 1-66. https://www.youtube. com/ watch? $=Y 1 w k Y 0 h A 23 s \& l i s t=L L t h r v 0 z \_y 4$--

Rahma, P. S. (2013). Penelitian Kualitatif.pdf. In Penelitian Kualitatif (Vol. 5, p. 8). yusuf.staff.ub. ac.id/files/2012/11/Jurnal-Penelitian-Kualitatif. pdf

Restusari, F. N., \& Farida, N. (2019). Instagram Sebagai Alat Personal Branding Dalam Membentuk Citra Diri (Studi Pada Akun Bara Pattiradjawane). Mediakom: Jurnal Ilmu Komunikasi, 3(2), 176-186. https://doi.org/10.35760/mkm. 2019.v3i2.2340

Ridho, T. (2016). Fenpmena pemanfaatan Instagram sebagai media personal branding.

Setiawan, R., \& Audie, N. (2020). Media Sosial Instagram Sebagai Presentasi Diri Mahasiswi Pendidikan Sosiologi Untirta. Community: Pengawas Dinamika Sosial, 6(1), 10. https://doi.org/ 10.35308/jcpds.v6i1.1792

Sheldon, P., \& Bryant, K. (2016). Instagram: Motives for its use and relationship to narcissism and contextual age. Computers in Human Behavior, 58, 89-97. https://doi.org/10.1016/j.chb.2015. 12.059

Suneki, \& Haryono. (2017). Paradigma Teori Dramaturgi Terhadap Kehidupan Sosial. Civis, 2(2), 111.

Tamimy, F. (2017). Sharing-mu, Personal Brandingmu, Menampilkan Image Diri dan Karakter di Media Sosial.

Widyastuti, D. A., Wiloso, P. G., \& Herwandito, S. (2017). Analisis Personal Branding Di Media Sosial (Studi Kasus Personal Branding Sha'an D'anthes Di Instagram). Jurnalinovasi, 11(1), 116. http://journal.binadarma.ac.id/index.php/jurnalinovasi/article/download/649/345

Achmad, E. S. (2020). Personal branding pada remaja melalui instagram.

Afriluyanto, T. R. (2018). Fenomena Remaja Menggunakan Media Sosial dalam Membentuk Identitas. KOMUNIKA: Jurnal Dakwah Dan Koтиnikasi, 11(2), 184-197. https://doi.org/10.24090/ komunika.v11i2.1365

Agustinna, K., Purnama, H., \& Abdurrahman, M. S. (2017). Kata kunci: Personal Branding, Instagram, Selebgram Keywords: Personal Branding, Instagram, Selebgram. Analisis Strategi Personal Branding Melalui Media Sosial Instagram, 4(1), 1028-1036. 
Dakwah, F., Komunikasi, D. A. N., Ar-raniry, U. I. N., \& Aceh, B. (2018). Etika berbusana (. 118. https://repository.ar-raniry.ac.id/id/eprint/4720/2/ NurulFaraiyah Binti Abu Bakar.pdf

Fitriyanti, N. (2017). Facebook dan Instagram sebagai media publishing karya komikus di Melati Komik Studio Surabaya. UIN Sunan Ampel Surabaya., 1, 1-476. https://doi.org/10.1017/ CBO9781107415324.004

Joko, B., Praktisi, P., \& Lia, D. (2014). Strategi Menciptakan, Mempertahankan Dan Menjual Personal Branding Jelang Pemilu 2014. Jurnal Visi Komunikasi, 13(02), 265-280.

Maulhayat, F., Kesuma, A. I., \& Amiruddin, H. (2018). Peran Instagram di Kalangan Mahasiswa Angkatan 2015 Fakultas Ilmu Sosial Universitas Negeri Makassar. 1-18. http://eprints.unm.ac.id/ 9871/\%0Ahttps://id.wikipedia.org/wiki/Instagra mSeiri

Mawarni, A. D. (2016). Analisis Isi pada Artikel Romansa di Zetizen. Com (Studi Analisis Isi Artikel Romansa pada Web Zetizen Periode 1 Oktober-30 November 2016 ). November, 1-10.

McNally, D., \& Speak, K. D. (2009). Be Your Own Brand: A breakthrough formula for standing out from the crowd. 1-141. https://www.bkconnection.com/static/Be_Your_Own_Brand_EXCER PT.pdf

Muhammad, H. (2016). Fashion Sebagai Komunikasi: Analisis Semiotis Atas Fashion Jokowi pada Pemilihan Presiden 2014. Icmr, 6-8.

Putri, D. M., Sos, S., \& Si, M. (2017). Analisis Retorika pada Pembentukan Personal Branding Sandiaga Uno Sebagai Pemimpin Publik Pilkada 2017 Oleh. 1-66. https://www.youtube. $\mathrm{com} /$ watch? $=$ Y 1 wkY0hA23s\&list=LLthrv0 y4_--

Rahma, P. S. (2013). Penelitian Kualitatif.pdf. In Penelitian Kualitatif (Vol. 5, p. 8). yusuf.staff. ub.ac.id/files/2012/11/Jurnal-Penelitian-Kualitatif.pdf

Restusari, F. N., \& Farida, N. (2019). Instagram Sebagai Alat Personal Branding Dalam Membentuk Citra Diri (Studi Pada Akun Bara Pattiradjawane). Mediakom: Jurnal Ilmu Komunikasi, 3(2), 176-186. https://doi.org/10.35760/mkm.2019. v3i2.2340

Ridho, T. (2016). Fenpmena pemanfaatan Instagram sebagai media personal branding.

Setiawan, R., \& Audie, N. (2020). Media Sosial Instagram Sebagai Presentasi Diri Mahasiswi Pendidikan Sosiologi Untirta. Community: Pengawas Dinamika Sosial, 6(1), 10. https://doi.org/10. 35308/jcpds.v6i1.1792

Sheldon, P., \& Bryant, K. (2016). Instagram: Motives for its use and relationship to narcissism and contextual age. Computers in Human Behavior, 58, 89-97. https://doi.org/10.1016/j.chb.2015.12. 059

Suneki, \& Haryono. (2017). Paradigma Teori Dramaturgi Terhadap Kehidupan Sosial. Civis, 2(2), 111.

Tamimy, F. (2017). Sharing-mu, Personal Branding$m u$, Menampilkan Image Diri dan Karakter di Media Sosial.

Widyastuti, D. A., Wiloso, P. G., \& Herwandito, S. (2017). Analisis Personal Branding Di Media Sosial (Studi Kasus Personal Branding Sha'an D'anthes Di Instagram). Jurnalinovasi, 11(1), 116. http://journal.binadarma.ac.id/index.php/jurnalinovasi/article/download/649/345. 